\title{
Senescence of Flag Leaves and Ears of Wheat Hastened by Methyl Jasmonate
}

\author{
J. Beltrano,* M. G. Ronco, E. R. Montaldi, and A. Carbone \\ Instituto de Fisiología Vegetal (INFIVE), Facultad de Ciencias Agrarias y Forestales, Facultad de Ciencias Naturales, UNLP, CC 327, \\ 1900 La Plata, Argentina
}

Received July 10, 1997; accepted January 5, 1998

\begin{abstract}
Treatment of flag leaves and ears of wheat plants with MJ (jasmonic acid methylester) $\left(10^{-5}\right.$ and $10^{-4} \mathrm{M}$ ) did not increase ethylene production, but it did accelerate senescence as indicated by the loss of chlorophyll. MJ also caused the closure of stomata, and consequently the rates of transpiration and photosynthesis decreased. Early maturity shortened the grain filling period, so the thousand grain weight was lower. Although ethylene elicited the same physiologic effects, the syndrome of senescence by $\mathrm{MJ}$ is independent of the former. We conclude that senescence and death in wheat are far from being elucidated; however, MJ and ethylene seem to participate in the phenomenon.
\end{abstract}

Key Words. Ear senescence-Ethylene-MJ-Methyl jasmonate-Triticum aestivum-Wheat.

Jasmonic acid (JA) (3-oxo-2-(-2'-cis-pentil)cyclopentane-1-acetic acid) and its derivatives constitute a new group of hormones of higher plants as well as fungi and algae (Davies 1987, Meyer et al. 1984, Sembnder and Parthier 1993, Tizio 1996). Levels determined by several methods are similar to those of other hormones, i.e. from $10 \mathrm{ng}$ to $3 \mu \mathrm{g} \mathrm{g}^{-1}$ fresh weight, in different tissues and species (Tizio 1996).

JA seems to be the most abundant form, but its methyl ester (MJ) is usually more active especially when it is applied exogenously (Falkenstein et al. 1991, Staswick

\footnotetext{
Abbreviations: ABA, abscisic acid; ACC, 1-amino-cyclopropane-1carboxylic acid; ANOVA, analysis of variance; AVG, aminoethoxyvinylglycine; ET, ethephon; FW, fresh weight; GC, gas chromatography; IRGA, infrared gas analyzer; JA, jasmonic acid; MJ, methyl jasmonate; Rubisco, D-ribulose-1,5-diphosphate carboxylase; STS, silver thiosulfate solution; TGW, thousand grain weight.

*Author for correspondence.
}

1992). The greater activity of MJ is probably because it is more volatile and is not ionized in the plant. In addition, JA is effective only when it is applied directly to the leaves, perhaps because it is less volatile than MJ (Farmer and Ryan 1992). Moreover, as a volatile compound, $\mathrm{MJ}$ is an effective natural signal among plants, although air turbulence may prevent the accumulation of enough jasmonate to cause a response in all situations.

Previous studies suggest that both JA and MJ have physiologic effects as growth inhibitors in several plant species (Dathe et al. 1981). If applied exogenously to plants, MJ produces effects such as induction of leaf senescence (Satler and Thimann 1981, Weidhase et al. 1987), promotion of abscission, root formation, and ethylene and $\beta$-carotene synthesis (Czapski and Saniewski 1985, Saniewski et al. 1987a, 1987b). Among the physiologic processes, senescence of detached leaves appears to be a promising model system for studying the mode of action of the JA group.

Senescence as induced by MJ is characterized by the drastic loss of chlorophyll, the degradation of Rubisco and the inhibition of its biosynthesis, and an increase of the respiratory rate and protease and peroxidase activity (Koda 1992, Maslenkova et al. 1990, Parthier 1990, Popova et al. 1988, Weidhase et al. 1987). In addition, MJ counteracts the antisenescence action of kinetin as ABA does, acting as an antagonist (Ueda and Kato 1980). However, the extent of senescence promotion by MJ depends on the plant species and the varieties used (Herrmann et al. 1989).

It is interesting that in mature tomatoes and preclimateric apples MJ induces the increase of ethylene production and increased levels of either of ACC synthase or ACC dioxygenase activity as well. It is well known that ethylene is involved in most of the senescence processes in fresh fruit (Saniewski et al. 1987a, 1987b) as well as in the leaves and ears of wheat (Beltrano et al. 1994). Although treatment with JA may cause an increased production of ethylene, the promotion of senescence in cu- 
cumber cotyledons was found to be rather independent of enhanced ethylene production (Abeles et al. 1989). On the other hand, Sanz et al. (1993) found that ethylene production in detached olive tree leaves treated with MJ was lower than in control, despite containing a greater amount of free ACC. Likewise, Saniewski et al. (1987a) observed that MJ applied to postclimateric apple fruits had a pronounced inhibitory effect on both ethylene production and ACC content. Hence it was reasonable to speculate that MJ could induce maturity and possibly senescence in wheat flag leaves and ears directly, without the involvement of ethylene. In this work we hypothesized that MJ promotes senescence independently of the ethylene levels in tissues.

\section{Materials and Methods}

Wheat (Triticum aestivum L.) cv. Buck Poncho plants, cultivated in 5-liter plastic pots, were used employing a mixture of soil and sand (3:1).

Plants were watered daily and fertilized once a week with halfstrength Hoagland solution (Hoagland and Arnon 1950). Neither symptoms of mineral deficiencies nor pest attacks were observed. Plants were grown in a greenhouse with a maximum photosynthetic photon flux density of $1,600 \mu \mathrm{mol} \mathrm{m} \mathrm{m}^{-2} \mathrm{~s}^{-1}$ in August and 2,500 $\mu \mathrm{mol} \mathrm{m} \mathrm{m}^{-2} \mathrm{~s}^{-1}$ in December, measured at midday with a radiometer (Licor quantum sensor LI-190 SA). The photoperiod was the natural of the locality (La Plata: $34^{\circ} 54^{\prime}$ SL).

Fresh air was supplied continuously to the greenhouse to prevent the accumulation of ethylene and $\mathrm{CO}_{2}$. The greenhouse atmosphere was sampled periodically and analyzed for $\mathrm{CO}_{2}$ content with an infrared gas analyzer (IRGA; Licor LI-6200) and for ethylene by GC as described by Beltrano et al. (1994).

After anthesis the following treatments were performed: water (control); $10^{-5} \mathrm{M}$ MJ solution, $10^{-4} \mathrm{M} \mathrm{MJ}$ solution, $4 \times 10^{-5} \mathrm{M}$ ET solution. Each treatment consisted of spraying lots of 15 plants with each solution every 7 days from postanthesis to hard dough stage in the late afternoon in an arrangement of four blocks. The experiments were conducted during 1991 and 1992, under similar conditions and in the same seasons. The results presented in this paper represent those obtained in 1992; they did not differ significantly from those of 1991.

Ethylene emission by flag leaves and ears was determined as described in Beltrano et al. (1994).

Stomatal conductance and transpiration of flag leaves were determined with a Licor porometer LI-1600. In the same leaves photosynthesis was measured with an IRGA (Licor LI-6200). Chlorophyll, as a characteristic symptom of senescence, was determined according to Morn and Porath (1980).

Data were statistically analyzed by the variance test (ANOVA), $p<$ 0.05 .

\section{Results and Discussion}

The emission of ethylene from wheat ears sprayed with $10^{-5}$ and $10^{-4} \mathrm{M} \mathrm{MJ}$ was lower than that of the control throughout the whole process of ear maturation and senescence, i.e. from postanthesis to the hard dough grain stage. Thus, when ears were sprayed with $10^{-5} \mathrm{M} \mathrm{MJ}$ at

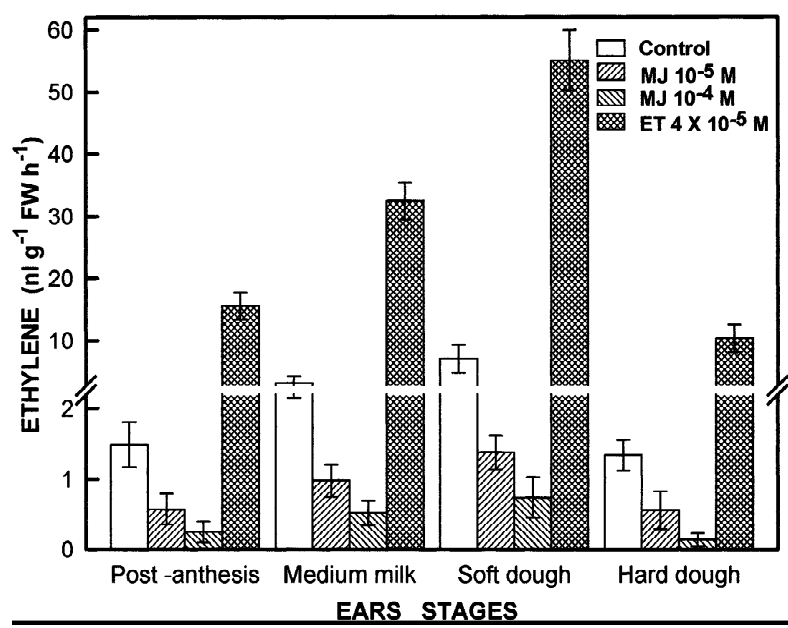

Fig. 1. Effect of $10^{-5} \mathrm{M} \mathrm{MJ}, 10^{-4} \mathrm{M} \mathrm{MJ}$, and $4 \times 10^{-5} \mathrm{M}$ ET on the emission of ethylene $\left(\mathrm{nL} \mathrm{g} \mathrm{g}^{-1} \mathrm{FW} \mathrm{h}^{-1}\right)$ from wheat ears from postanthesis to hard dough grain stages. The means for ethylene emission are presented with S.E.

every stage of development the emission of ethylene was between 10 and $20 \%$ of the emission in untreated ears in all grain stages; ears sprayed with $4 \times 10^{-5} \mathrm{M}$ ET liberated larger quantities, as was found previously (Beltrano et al. 1994) (Fig. 1). It is important to mention that Beltrano et al. (1994) reported that the emission of ethylene from wheat ears treated with AVG, a specific inhibitor of ethylene synthesis, induced a significant reduction in its production. Likewise, silver ions (STS), which act as nonspecific antiethylene agents, inhibiting its action or incorporation into plant tissues, also resulted in a decrease in the emission of ethylene from the ears, but in no case was the ethylene production suppressed completely.

Flag leaves sprayed with MJ in the postanthesis stage produced ethylene levels similar to those of the control; however, in the medium milk and soft dough grain stages those flag leaves treated with a high concentration of MJ $\left(10^{-4} \mathrm{M}\right)$ liberated higher quantities. In the hard dough grain stage the emission of ethylene was negligible (Fig. 2). These results agree with those of Abeles et al. (1989), who showed that treatment with JA promotes senescence in cucumber cotyledons. Likewise, Montague (1997) did not find evidence that JA-treated oat stem segments produced enough ethylene to influence the growth of the segments. In contrary, Sanz et al. (1993) found that in olive leaf discs floating on $45 \mu \mathrm{M} \mathrm{MJ}$, the liberation of ethylene was increased.

Among the main symptoms of the senescence syndrome, the loss of chlorophyll is the parameter to estimate the process. In this work, the content of chlorophyll in flag leaves decreased in parallel and progressively, although more rapidly in plants treated with MJ (in both concentrations). Already in the postanthesis stage the dif- 


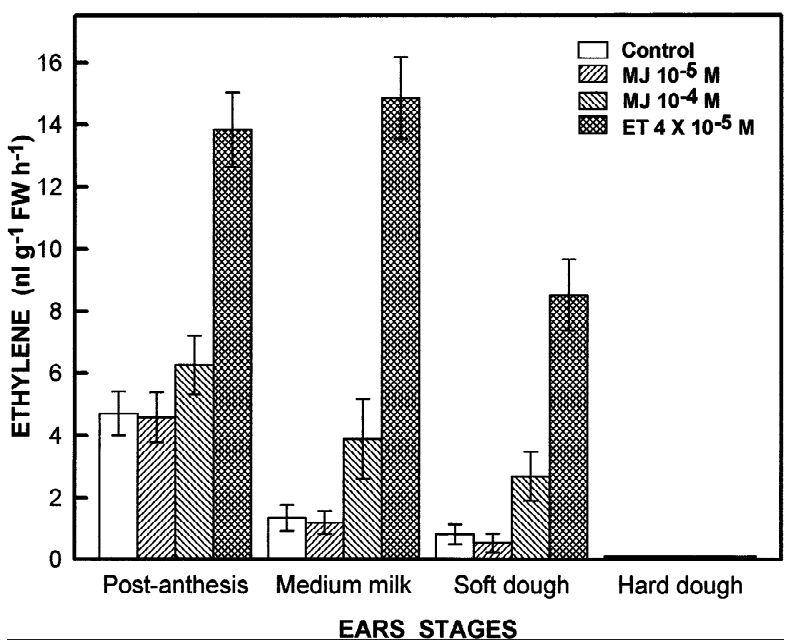

Fig. 2. Effect of $10^{-5} \mathrm{M} \mathrm{MJ}, 10^{-4} \mathrm{M} \mathrm{MJ}$, and $4 \times 10^{-4} \mathrm{M}$ ET on the emission of ethylene $\left(\mathrm{nL} \mathrm{g}^{-1} \mathrm{FW} \mathrm{h}^{-1}\right)$ from wheat flag leaves from postanthesis to hard dough grain stages. The means for ethylene emission are presented with S.E.

ferences from the control were highly significant (by $25 \%$ and $40 \%$ less than the control) (Fig. 3). Similarly, Weidhase et al. (1987) showed that JA induced a rapid chlorophyll degradation in barley leaf segments. Similar results were obtained in other monocot and dicot species by Ueda et al. (1981), Popova et al. (1988), Herrmann et al. (1989), Maslenkova et al. (1990), Parthier (1990), and Koda (1992). Some authors pointed out that the concentrations of JAs used (in the range of $10^{-5}$ to $10^{-3} \mathrm{M}$ ) might act as a toxic factor (Horton 1991, Tizio 1996).

Moreover, it is well known that ethylene also caused diminution of the chlorophyll content of leaves, as shown previously (Abeles et al. 1989, Beltrano et al. 1994).

The results shown in Fig. 4 indicate that MJ at both concentrations $\left(10^{-5}\right.$ and $\left.10^{-4} \mathrm{M}\right)$ induced stomatal closure of flag leaves at all grain stages; in soft dough stage the stomatal closure was highly significant. This response confirms the results obrtained by Sanz et al. (1993), which demonstrate that in olive leaves, $45 \mu \mathrm{M}$ MJ elicited the closure of the stomates. Similarly, Satler and Thimann (1981) found that oat leaf segments floated on $15 \mu \mathrm{M} \mathrm{MJ}$ in the light provoke some stomatal closure as measured by porometry. Contrarily, Horton's (1991) experiments, using $\mathrm{MJ}$ in concentrations similar to those used in the present paper, did not provide evidence that $\mathrm{MJ}$ acts as a primary modulator of stomatal closure in barley, although it was effective when it was applied at a very high concentration $(1 \mathrm{~mm})$. Consequently, it was logical to explain the diminution of transpiration and photosynthetic activities because of this closure (Figs. 5 and 6). Likewise, it must be pointed out that ET produces some of the same physiological effects as MJ.

$\mathrm{MJ}$, at both concentrations $\left(10^{-5}\right.$ and $\left.10^{-4} \mathrm{M}\right)$, pro-

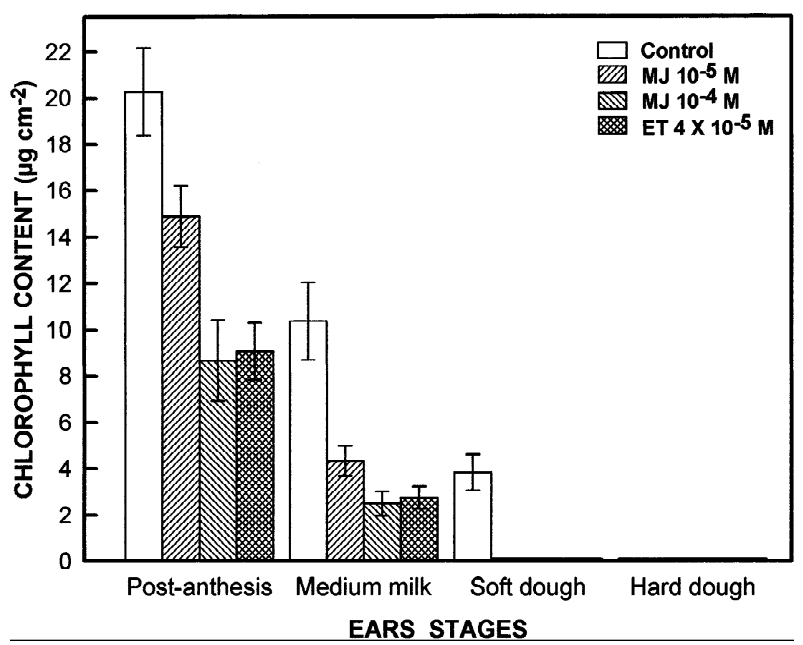

Fig. 3. Effect of $10^{-5} \mathrm{M} \mathrm{MJ}, 10^{-4} \mathrm{M} \mathrm{MJ}$, and $4 \times 10^{-5} \mathrm{M}$ ET on the chlorophyll content $\left(\mu \mathrm{g} \mathrm{cm}^{-2}\right)$ of wheat flag leaves from postanthesis to hard dough grain stages. The means for chlorophyll content are presented with S.E.

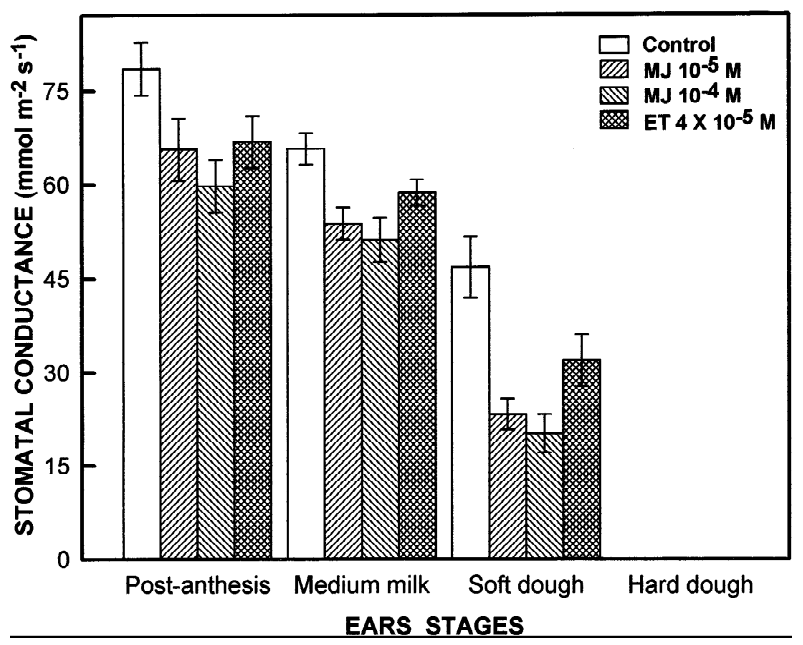

Fig. 4. Effect of $10^{-5} \mathrm{M} \mathrm{MJ}, 10^{-4} \mathrm{M} \mathrm{MJ}$, and $4 \times 10^{-5} \mathrm{M}$ ET on stomatal conductance $\left(\mathrm{mmol} \mathrm{m}^{-2} \mathrm{~s}^{-1}\right)$ of wheat flag leaves from postanthesis to hard dough grain stages. The means for stomatal conductance are presented with S.E.

duced a significant reduction in the chlorophyll content of flag leaves and less in the photosynthetic rate. It provoked a shortening of the grain filling period, reaching maturity 7 days in advance compared with the control, and a statistically significant, but rather small diminution, of the TGW (Table 1). The $40 \%$ reduction of the chlorophyll content alone affected the TGW by $10 \%$. Evidence in the literature shows that plant species may contain an excess amount of leaf chlorophyll (Gifford 1987). On the other hand, it has been demonstrated in numerous species that the yield was not diminished for a 


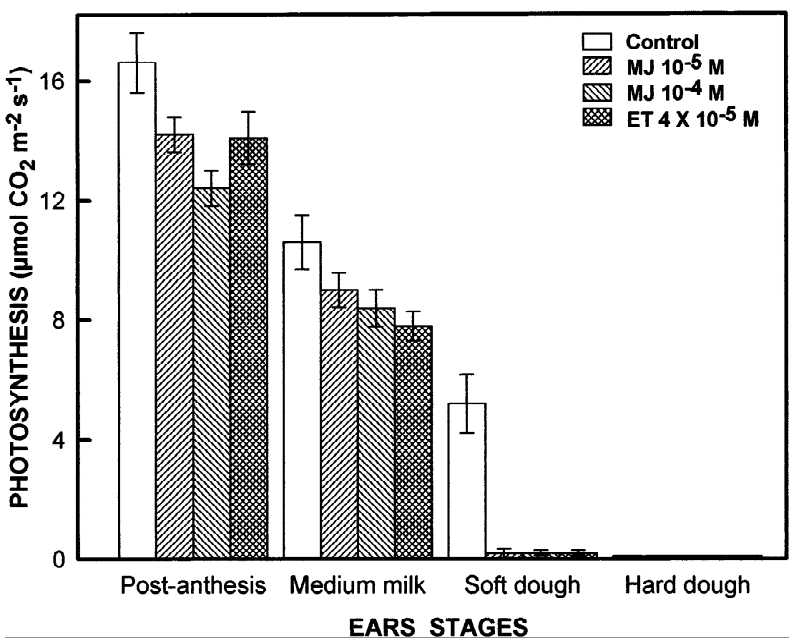

Fig. 5. Effect of $10^{-5} \mathrm{M} \mathrm{MJ}, 10^{-4} \mathrm{M} \mathrm{MJ}$, and $4 \times 10^{-5} \mathrm{M}$ ET on photosynthesis ( $\mu \mathrm{mol} \mathrm{CO} \mathrm{CO}_{2}^{-2} \mathrm{~s}^{-1}$ ) of wheat flag leaves from postanthesis to hard dough grain stages. The means for photosynthesis are presented with S.E.

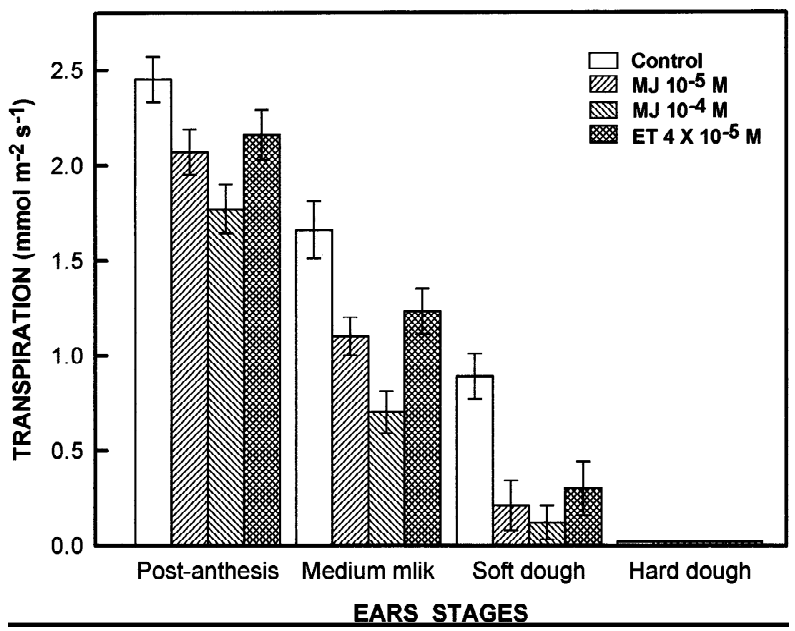

Fig. 6. Effect of $10^{-5} \mathrm{M} \mathrm{MJ}, 10^{-4} \mathrm{M} \mathrm{MJ}$, and $4 \times 10^{-5} \mathrm{M}$ ET on transpiration $\left(\mathrm{mmol} \mathrm{m} \mathrm{m}^{-2} \mathrm{~s}^{-1}\right.$ ) of wheat flag leaves from postanthesis to hard dough grain stages. The means for transpiration are presented with S.E.

reduction the chlorophyll content (Estill et al. 1991, Ferguson 1974, Kirchhoff et al. 1989, Pettigrew et al. 1989).

On the whole, MJ caused an accelerated senescence per se, i.e. MJ was not induced by an increase in the ethylene synthesis, although ethylene elicits the same physiologic phenomenon. It is obvious then that the hypothesis was confirmed. At this point it is interesting to mention that Monague (1997) reported similarly, although in other biological system, that JA action is not correlated with ethylene production. Likewise, Porat et al. (1995) concluded also that JAs are not involved in the
Table 1. Average final dry weight $(\mathrm{g})$ of the grains treated with $10^{-5}$ $\mathrm{M}, \mathrm{MJ}, 10^{-4} \mathrm{M}, \mathrm{MJ}$, and $4 \times 10^{-5} \mathrm{M}$ ethephon. Values are the mean of 15 replications. Means followed by the same letter do not differ at the $5 \%$ level of significance (ANOVA).

\begin{tabular}{ll}
\hline Treatments & Grain weight (TGW) \\
\hline Control (water) & $37.73 c$ \\
MJ & \\
$\quad 10^{-5} \mathrm{M}$ & $34.90 a b$ \\
$\quad 10^{-4} \mathrm{M}$ & $34.26 a$ \\
Ethephon & $35.90 \mathrm{~b}$ \\
$\quad 4 \times 10^{-5} \mathrm{M}$ & \\
\hline
\end{tabular}

regulation of ethylene production during the senescence of pollination-induced orchid flowers. Senescence still remains an enigma that involves many substances and factors.

Acknowledgments. We thank Prof. Wilfred Dathe of the University of Halle (Saale), Germany, for the sample of MJ; Ofelia Ocampo and Olga Peluso for technical assistance; and the Consejo Nacional de Investigaciones Científicas y Técnicas (CONICET), Argentina, for financial support. M. Ronco and J. Beltrano are researchers of CIC-BA.

\section{References}

Abeles FB, Hershberger WL, Dunn L (1989) Hormonal regulation and intracellular localization of a $33-\mathrm{kDa}$ cationic peroxidase in cucumber cotyledons. Plant Physiol 89:664-668

Beltrano J, Carbone A, Montaldi ER, Guiamét JJ (1994) Ethylene as promoter of wheat grain maturation and ear senescence. Plant Growth Regul 15:107-112

Czapski J, Saniewski M (1985) Effect of methyl jasmonate on carotenoides in tomato fruits. Gartenbauwissenschaft 50:35-37

Dathe W, Ronsch H, Preiss A, Schade W, Semdbner G, Schreiber K (1981) Endogenous plant hormones of the broad bean Vicia faba L. (-)-jasmonic acid, a plant growth inhibitor in pericarp. Planta 153:530-535

Davies PJ (1987) The plant hormones: Their nature, occurrence, and function. In: Davies PJ (ed) Plant hormones and their role in plant growth and development. Martinus Nihoff, Dordrect, The Netherlands, pp 1-11

Estill K, Delaney RH, Smith WK, Ditterline RL (1991) Water relations and productivity of alfalfa leaf chlorophyll variants. Crop Sci 31:1229-1233

Falkenstein E, Groth B, Mithöfer A, Weiler EW (1991) Methyl jasmonate and linolenic acid are potent inducers of tendril coiling. Planta 185:316-322

Farmer EE, Ryan CA (1992) Octadecanoid precursors of jasmonic acid activate the synthesis of wound-inducible proteinase inhibitors. Plant Cell 4:129-134

Ferguson H (1974) Use of variety isogenes in plant water-use efficiency studies. Agric Meteorol 14:25-30

Gifford RM (1987) Barriers to increasing crop productivity by genetic improvement in photosynthesis research. In: Biggins $\mathbf{J}$ (ed) Progress in photosynthesis research. Vol 4. Martinus Nijhoff, Dordrecht, The Netherlands, pp 377-384

Herrmann EM, Lehmann J, Peterson A, Sembdener G, Weidhase RA, 
Parthier B (1989) Species and tissue specificity of jasmonateinduced abundant proteins. J Plant Physiol 134:703-709

Hoagland DR, Arnon DI (1950) The water-culture method for growing plants without soil. Circular 347. California Agricultural Experiment Station. The college of Agriculture, University of California. Berkeley

Horton RF (1991) Methyl jasmonate and transpiration in barley. Plant Physiol 96:1376-1378

Kirchhoff WR, Hall AE, Thomson WW (1989) Gas exchange, carbon isotope discrimination, and chlorophyll ultrastructure of a chlorophyll-deficient mutant of cowpea. Crop Sci 29:109-115

Koda Y (1992) The role of jasmonic acid and related compounds in the regulation of plant development. Int Rev Cytol 135:155-199

Maslenkova LT, Zanev Y, Popova LP (1990) Oxygen-evolving activity of thylakoids from barley plants cultivated on different concentrations of jasmonic acid. Plant Physiol 93:1316-1320

Meyer A, Miersch O, Buttner C, Dathe W, Sembdener G (1984) Occurrence of the plant growth regulator jasmonic acid in plants. J Plant Growth Regul 3:1-8

Montague MJ (1997) Exogenous jasmonic and abscisic acids act differentially elongating tissues from oat stem segments. J Plant Growth Regul 16:11-19

Morn R, Porath D (1980) Chlorophyll determination in intact tissues using $N, N$-dimethylformamide. Plant Physiol 65:478-479

Parthier B (1990) Jasmonates: Hormonal regulators or stress factors in leaf senescence? J Plant Growth Regul 9:57-63

Pettigrew WT, Hesketh JD, Peters DB, Woolley JT (1989) Characterization of canopy photosynthesis of chlorophyll-deficient soybean isolines. Crop Sci 29:1025-1029

Popova LP, Tsonev TD, Vaklinova SG (1988) Changes in some photosynthetic and photorespiratory properties in barley leaves after treatment with jasmonic acid. J Plant Physiol 132:257-261

Porat R, Reiss N, Atzorn R, Halevy AH, Borochov A (1995) Examination of the possible involvement of lipoxygenase and jas- monates in pollination-induced senescence of Phalaenopsis and Dendrobium orchid flowers. Physiol Plant 94:205-210

Saniewski M, Czapski J, Nowaski J, Lange E (1987a) The effect of methyl jasmonate on ethylene and 1-aminocyclopropane-1carboxylic acid production in apple fruits. Biol Plant 29:199_ 203

Saniewski M, Nowacki J, Czapski J (1987b) The effect of methyl jasmonate on ethylene production and ethylene-forming enzyme activity in tomatoes. J Plant Physiol 129:175-180

Sanz L, Fernandez-Maculet J, Gomez E, Vioque B, Olias JM (1993) Effect of methyl jasmonate on ethylene biosynthesis and stomatal closure in olive leaves. Phytochemistry 33:285-289

Satler SO, Thimann KV (1981) Le jasmonate de méthyle: Nouveau et puissant promoteur de la sénescence des feuilles. C R Acad Sci Series 293:735-740

Sembdner G, Parthier B (1993) The biochemistry and the physiological and molecular actions of jasmonates. Annu Rev Plant Physiol Plant Mol Biol 44:569-589

Staswick PE (1992) Jasmonate, genes and fragrant signals. Plant Physiol 99:804-807

Tizio R (1996) Jasmonic acid and their derivatives as plant growth regulators. Biocell 20:1-10

Ueda J, Kato J (1980) Isolation and identification of a senescencepromoting substance from wormwood (Artemisia absinthium L.). Plant Physiol 66:246-249

Ueda J, Kato J, Yamane H, Takahashi N (1981) Inhibitory effect of methyl jasmonate and its related compounds on kinetin-induced retardation oat leaf senescence. Physiol Plant 52:305-309

Weidhase RA, Lehmann J, Kramell H, Sembdner G, Parthier B (1987) Degradation of ribulose-1,5-biphosphate carboxylase and chlorophyll in senescing barley leaf segments triggered by jasmonic acid methyl ester and counteraction by cytokinin. Physiol Plant 69:161-166 